\section{UNIVERSITY COURSES IN THE U.S.S.R.}

$\mathrm{O}^{\mathrm{n}}$ September 1, 1955, new syllabuses came into force for first-, second-and third-year students of all university faculties in the U.S.S.R. These have been described by M. G. Uroyev, of the Central Board of Universities and Institutes of Law and of Economics.

Fourth-and fifth-year students continue to follow the old courses; but there is an important addition for students in the faculties of philology, history, physics and mathematics, biology, chemistry and geography. In their seventh term they will take a course on teaching methods and, in their eighth term, will do teaching practice in schools for six weeks; during this time they will have no lectures or other work.

For a number of subjects one of the main weak. nesses of the old syllabuses was that they produced specialists of too narrow a type. One of the chief demands of the new syllabuses is that they should provide conditions suitable for the training of 'broad' specialists - people with a command of the fundamentals of the sciences but with a proper preparation for work in various branches of industry and culture.

Subjects of general scientific and technical importance are given more weight in the syllabuses; for closely related degree subjects within the faculties of biology, geology, philology and geography there will be unification of the gencral theoretical grounding given to all students. For the first two or three years students taking kindred subjects will follow exactly the same courses, covering the same ground and devoting the same amount of time to various courses. For example, for the six different degree courses which can be taken in geology, there are twenty. seven courses which are the same for all students. These take up to 66-68 per cent of the total time of the syllabus, leaving $32-34$ per rent of their time for special subject courses.

The new syllabuses provide for broader subject divisions than the old and do not, as a rule, allow for specialization within the chosen subject. Such excessively specialized degree subjects as, for example, 'the editing of literary and political writings', 'the economics of the countries of the non-Soviet East', 'world economics', 'the history of international relations', 'Darwinism and genetics' have been discarded. Inorganic chemistry, organic chemistry and analytical chemistry, which used to be independent degree subjects, have now become subjects in which one specializes inside the framework of a general chemistry degree.

The number of hours available for faculty courses and seminars has been reduced. Universities now have the right to decide for themselves the subjects and extent of faculty courses and seminars, and to discuss and approve for themselves the advance plans produced for such courses. In this way such courses and sominars will reflect the scientific work being done in the given university.

In the case of students in the faculty of biology, the reduction in the amount of timo allowed for their faculty courses and seminars has made it possible to increase the time devoted to learning a foreign language, to studying teaching methods of their subject, and to physics, chemistry and botany and higher mathematics.
The importance of the independent work done by students is recognized and reflected in the new syllabuses in the following way: the number of lectures and classes at which attendance each week is obligatory has been cut down; certain classes, in which the material dealt with can well be mastered by the student independently, have been done away with altogether; and the number of pieces of independent work required from the student in different courses has been increased.

The increase in the time given to teachers' training is of major significance; the main task now is to train teachers for the senior classes of the secondary schools. As from 1956, not less than 80 per cent of each year's graduates in the faculties of philology, history, geography and biology, and not less than 60 per cent from the faculties of chemistry and physics and mathematics, will be going to work as secondary school teachers.

The actual titles of the qualification received by graduate teachers has also been changed: the diploma given to a graduate used to read "qualified in history (or mathematics)" but will now read "qualified in history and as a teacher of history in secondary schools"*.

* Translators' note. The translators, who have carried out their task on behalf of the Society for Cultural Relations, write that the way in which Soviet and British university 'technical terms' have been equated in the translation is not consistent: Soviet graduates, for example, do not receive degrees, but diplomas. The word 'term' has been used for translating the Russian 'semestr', though this is really a half-year; but 'faculty' has been used in the Soviet way, although their faculties correspond to our schools or departments.

\section{OVERSEAS FOOD CORPORATION}

\section{REPORT FOR 1954-55}

$T$ HE annual roport of the Overseas Food Cor. poration for the year ended March 31, 1955*, is the last report which the Corporation will publish, since the balance of funds made available for investigating the economics of mechanized and partly mechanized agriculture under tropical conditions has been transferred to the Colonial Development and Welfare Fund for the use of the newly established Tanganyika Agricultural Corporation, which will continue the investigations until September 1957 and report on them in due course. The legislation establishing the new Corporation provides also for the dissolution of the Overseas Food Corporation, and accordingly this final report is accompanied not only by the usual statement of accounts for the year but also by an interim review of the work of the whole undertaking from its inception. Some of the findings and conclusions merely confirm those of other workers in the Colonial Empire; but others are original, and the repor's should be of value to many concerned with the development of tropical agriculture both in East Africa and elsewhere. Moreover, it indicates the excollent work carried out not merely by the Scientific Department but also in land clearing and development. The African Tenant Farmers Scheme is developing satisfactorily in all three areas, and results have justified a continued extension of the Scheme. There is now every probability of consolidating one of the Corporation's original areas, Urambo, into an economic communal enterpriso based on a flue-cured tobacco economy, and experience gained

* Overseas Food Corporation. Annual Report and Statement of Accounts for the Year ended 31st March, 1955. Pp. viii + $183+8$ plates. (London: H.M.S.O., 1955.) 6s. 6d. net. 